\title{
Quantitative and Morphometric Evaluation of the Foramina Nutricia in the Long Bones of the Upper and Lower Extremities in Anatolian Population
}

\author{
Anadolu Toplumunda Üst ile Alt Ektremite Uzun Kemiklerindeki Foramen Nutricium'ların \\ Kantitatif ve Morfometrik Olarak Değerlendirilmesi
}

\author{
Muhammet Bora Uzuner', Mert Ocak², Ferhat Geneci33, Necdet Kocabıyık4, Mustafa F. Sargon², \\ Asaad AI-Shouk ${ }^{5}$ \\ ${ }^{1}$ Department of Anatomy, Kafkas University Faculty of Medicine; ${ }^{2}$ Department of Anatomy, Hacettepe University Faculty of Medicine; \\ ${ }^{3}$ Department of Anatomy, Yildirım Beyazıt University Faculty of Medicine; ${ }^{4}$ Department of Anatomy, Sağllk Bilimleri University \\ Gülhane Medical School, Ankara, Turkey; ${ }^{5}$ Department of Anatomy, University of Al Qadisiyah Faculty of Medicine, Iraq
}

\section{ABSTRACT}

Aim: This study is aimed to examine the nutrient foramina of the upper and lower extremities regarding to their numbers and localizations.

Material and Method: Totally; 576 long bones of upper and lower extremities were examined. Each of these bones were divided into 3 regions equally as proximal, distal and middle parts. The measurements were done by using a $80^{*} 0.38 \mathrm{~mm}$ needle.

Results: In the comparison of humerus and femur; a single nutrient foramen was found in the middle part of humerus in $78.7 \%$ and in the proximal part of femur in $55.2 \%$ of the bones. Double nutrient foramina were detected in $70.8 \%$ on middle part of humerus and $44.2 \%$ on proximal part of femur and $48.3 \%$ on middle part of femur. We only observed a single foramen in radius and fibula. It was in proximal part of radius with a ratio of $52.7 \%$ and in middle part with a ratio of $47.3 \%$. However in fibula, a single foramen was found in the middle part of the bones with a ratio of $79.7 \%$. A single nutrient foramen was found in proximal part of ulna in $73.6 \%$ and in middle part in $26.4 \%$. The tibia had a single nutrient foramen in its proximal part in $98.3 \%$.

Conclusion: Statistical difference of localization of foramen nutricium in comparative bones was determined when this study was examined macroanatomically. These results give new data to the literature by the view of not only the side of anatomy but also the side of anthropology. However this is very important for the surgeons who are interested microvascular bone transfer and fracture treatment.

Key words: foramina nutricium; long bone; upper extremity; lower extremity; comparison; quantification
ÖZET

Amaç: Bu çalıșmada üst ve alt ekstremitelerde bulunan foramen nutricium'ların sayı ve lokalizasyonu açısından incelenmesi amaçlandı.

Materyal ve Metot: Toplam 576 üst ve alt ekstremitede bulunan uzun kemik incelendi. Bu kemiklerden her biri, proksimal, distal ve orta olmak üzere 3 eșit parçaya ayrıldı. Foramen nutricium'ların ölçümleri için $80 \times 0,38 \mathrm{~mm}$ ölçülerinde iğne kullanılarak yapıldı.

Bulgular: Humerus ve femur karșılaștırıldığında; humerus'ların orta kısmında \%78, 7'lik bir oranda, femur'ların ise proksimal kısmında \%55,2'lik bir oranda tek bir foramen nutricium tespit edildi. Çift nutrient foramenler incelendiğinde; humerus'un orta kısmında \%70,8, femur proksimalinde \%44,2, femur orta kısmında $\% 48,3$ oranında bulundu. Sadece radius ve fibula'da tek bir nutrient foramen'e rastlandı. Radius'un proksimal kısmında \%52,7 oranında, orta kısımda \%47,3 oranında foramen nutricium'a rastlandı. Fibula'nın \%79,7'sinde orta kısmında tek bir foramen nutricium, ulna'nın proksimalinde $\% 73,6$, orta bölümününde $\% 26,4$ 'ünde tek bir foramen nutricium bulundu. Tibia'nın proksimalinde \%98,3 oranında tek bir nutrient foramene sahipti.

Sonuç: Makro anatomik olarak incelendiğinde; karșılaștırılan kemiklerde foramen nutricium lokalizasyonlarında istatiksel olarak fark tespit edildi. Bu sonuçlar anatomik ve antropolojik açıdan literatüre yeni bilgiler katmaktadır. Bununla beraber mikrovasküler kemik transferi ve kırık tedavileri ile ilgilenen cerrahlar açısından önem tașımaktadır.

Anahtar kelimeler: foramen nutricium; uzun kemik; üst ekstremite; alt ekstremite; karsıllastırma; kantitatif 


\section{Introduction}

Bones are richly supplied by blood vessels. The most evident blood supply is provided by arteria nutricia. These arteries are independent branches of adjacent arteries found outside of the periosteum. Located within the bones in a bent position, they face towards the compact part of the long bones through the foramina nutricia. Loss of blood flow in the epiphysis or other parts of the bone results in the death of the bone (avascular necrosis). In some type of fractures, bigger necrosis might occur $^{1}$. In the aftermath of a mandibular resection, Ferrari et al. ${ }^{2}$ succeeded in using dental implants located upon the free fibula flap, during the treatment of the jaw osteonecrosis occurring in the mandible of a patient who had been using intravenous bisphosphonates. In Şengezer' $s^{3}$ study, the free osteocutaneous fibula flap and penis reconstruction has been applied. Data on the location and the number of the foramina nutricia is important in order to preserve blood circulation during certain surgeries or during trauma and fractures' treatment. In our study, the number and the locations of the foramina nutricia found in the long bones of the upper and lower extremities have been compared.

\section{Material and Method}

The study was conducted with the bones of cadavers amongst the Anatolian society, whose age and sex were unknown. A total of 576 long bones found in the Faculty of Medicine at Hacettepe University and in the GATA Anatomy Department were scrutinized. The examined bones consist of 132 humeri, 107 ulnae, 133 radii, 131 femora, 118 tibiae and 87 fibulae. Each of the bones measured by a ruler was divided into three sections; the proximal, middle and distal section. On the other hand we use forminal index. Calculation of the foraminal index: The Location of all nutrient foramina was determined by calculating a foraminal index (FI) using the formula: $\mathrm{FI}=(\mathrm{DNF} / \mathrm{TL}) \mathrm{x} 100$. $\mathrm{DNF}=$ the distance from the proximal end of the bone to the nutrient foramen. $\mathrm{TL}=$ total bone length ${ }^{7,14,16}$. The number and the locations of the foramina nutricia found in these areas were defined. The gathered data was evaluated statistically. In this study a needle of dimensions $80 \mathrm{mmx} 0.38 \mathrm{~mm}$ (21 gauge) was used. Foramina nutricia into which the needle could not enter, were evaluated as secondary foramina nutricia and were not included in the study. Statistical data were analaysed via the IBM SPSS statistics premium $23 \mathrm{~V}$ program. Fisher's exact test were used in the analysis of data conducted via the SPSS program.

\section{Results}

In 94 of the humeri single foramen nutricium was observed (Fig. 1b). 9 of them were located in the proximal one-third of the corpus, 74 were located in the middle third and 11 were located in the distal third of the corpus. Meanwhile, double foramina nutricia were observed in 12 of the humeri. 7 of them were located in the proximal third and 17 in the middle third. The observed secondary foramina nutricia in 26 of the bones were not included in the study. Single foramen nutricium was found in the 58 femora (Fig. 2a). 32 of them were located in the proximal third, 25 in the middle third and 1 was located in the distal third. Double foramina nutricia in the femur were defined in a total of 60 bones. 53 of them were located in the proximal third, 58 in the middle third and 9 were located in the distal third. The secondary foramina nutricia which were found in 8 of the femora were not evaluated. The number of the single and double foramina nutricia which were found in the humerus and the femur were compared via the Pearson Chi-Square test. A significant difference was found among the numbers of the single foramina nutricia, but no significant difference was found among the numbers of the double foramina nutricia $(\mathrm{p}<0.09)$. Nevertheless, the overall number of the double foramina nutricia was found to be the highest in the middle section. Meanwhile, in 5 of the femor; a triple foramina nutricia were observed. 5 of them were located in the proximal third, 7 in the middle third and 3 in the distal third. However, due to the fact that no triple foramina nutricia were found in the humerus, no comparison was made (Table 1). Single foramen nutricium was observed in all of 129 radii that were included in the study (Fig. 1a). 68 of them were located in the proximal third and 61 in the middle third. 14 radii where secondary foramina nutricia found were not included in the evaluation. Single foramen nutricium was found in all of the 79 fibulae that were part of the study (Fig. 2c). 4 of them were found in the proximal third, 63 in the middle third and 12 in the distal third. In 8 of the fibulae, secondary foramina nutricia were found and they were not evaluated. The numbers of foramina nutricia that were found in the radius and the fibula were compared via the Pearson Chi-Square Test and the difference between them was found to be statistically significant $(p<0.0001)$ (Table 2$)$. In all of the 87 ulnae included in our research, a single foramen nutricium was found (Fig. 1c). 64 of them were located in the proximal third while 23 were in the middle third. 30 of the ulnae where secondary foramina nutricia found were not included in the evaluation. In almost all of the 118 tibiae, 


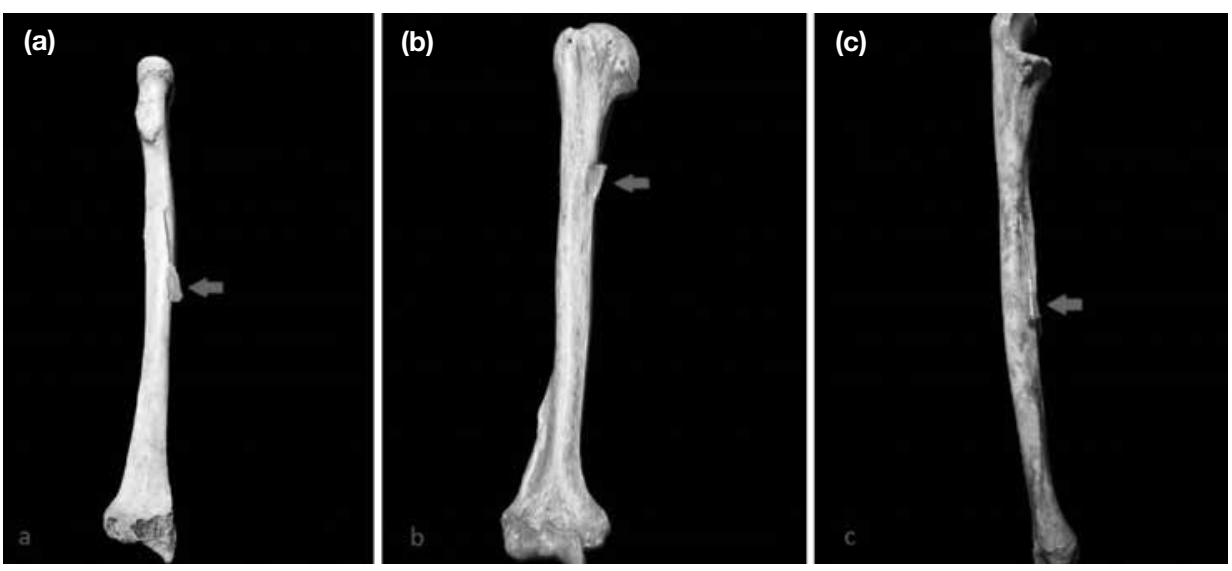

Figure 1. a-c. The nutrient foramen in radius (a). The nutrient foramen in humerus (b). The nutrient foramen in ulna (c).
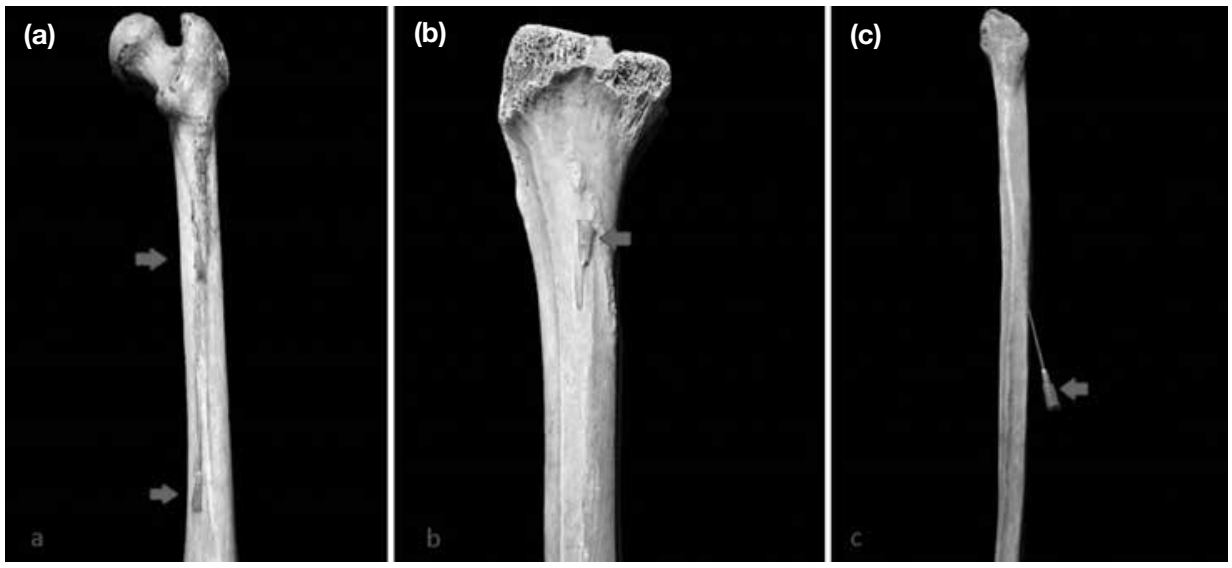

Figure 2. a-c. Photograph showing the nutrient foramina in femur (a). Photograph showing the nutrient foramen in tibia (b). Photograph showing the nutrient foramen in fibula (c).

a single foramen nutricium was observed, whereas only in 1 tibia double foramina nutricia was noticed (Fig. 2b). While a majority of 115 single foramina nutricia were located in the proximal third, only one single foramen nutricium was observed in each of the other two thirds (i.e.: in the middle and the distal third). When compared via the Pearson Chi-Square Test, the difference between the tibia and the ulna was found to be significant $(p<0.0001)$. In the proximal section of one of the tibiae two foramina nutricia were observed. However, due to the fact that no double foramina nutricia were found in the ulna, no comparison was able to be made (Table 3 ).

\section{Discussion}

The nutrient artery covers about $50 \%$ of the bone blood supply ${ }^{4}$. Kopuz et al. ${ }^{6}$ mentioned that nutrient foramina of radius and ulna are related with the region that has healing problems on forearm. Due to the existence of an injury risk in the bone artery of a fracture emerging very close to the foramen nutricium, a problem in the bone blood supply might occur. Brakenbury et al. ${ }^{5}$ reported that in isolated ulnar diaphyseal fractures, the bonding problem is not related to the foramina nutricia, but it is observed more often in the middle and distal sections that are poorly supplied by the nutrient artery. For this reason, the number and locations of the foramen nutrientis are important from a clinical viewpoint.

It is noted that in spite of the similarities in the materials used in studies about the foramen nutricium, these studies yield differing results due to the selected methods of the studies. In our study, we compared the number and the locations of the foramina nutricia found in the long bones of the upper and lower extremities. It is expected that the observed statistical differences related to the number and locations of the foramina nutricia will contribute to the way of the selection of the material that will be used in other studies as well as to future clinical studies. 
Table 1. Comparison between number and location of nutrient foramen in humerus and femur

\begin{tabular}{lcccc}
\hline & Location & Humerus N (\%) & Femur N (\%) & Total N (\%) \\
\hline Single Foramen Nutricium & Proximal & $9(9.6 \%)$ & $32(55.2 \%)$ & $41(27 \%)$ \\
& Middle & $74(78.7 \%)$ & $25(43.1 \%)$ & $99(65.1 \%)$ \\
& Distal & $11(11.7 \%)$ & $1(1.7 \%)$ & $12(7.9 \%)$ \\
Double Foramina Nutricia & Total & $94(100 \%)$ & $58(100 \%)$ & $152(100 \%)$ \\
& Proximal & $7(29.2 \%)$ & $53(44.2 \%)$ & $60(41.7 \%)$ \\
& Middle & $17(70.8 \%)$ & $58(48.3 \%)$ & $75(52.1 \%)$ \\
& Distal & 0 & $9(7.5 \%)$ & $9(6.3 \%)$ \\
& Total & $24(100 \%)$ & $120(100 \%)$ & $144(100 \%)$ \\
\hline
\end{tabular}

Table 2. Comparison between number and location of nutrient foramen in radius and fibula

\begin{tabular}{lcccc}
\hline & Location & Radius N (\%) & Fibula N (\%) & Total N (\%) \\
\hline Single Foramen Nutricium & Proximal & $68(52.7 \%)$ & $4(5.1 \%)$ & $72(43.6 \%)$ \\
& Middle & $61(47.3 \%)$ & $63(79.7 \%)$ & $124(59.6 \%)$ \\
& Distal & 0 & $12(15.2 \%)$ & $12(5.8 \%)$ \\
& Total & $129(100 \%)$ & $79(100 \%)$ & $208(100 \%)$ \\
\hline
\end{tabular}

Table 3. Comparison between number and location of nutrient foramen in ulna and tibia

\begin{tabular}{lcccc}
\hline & Location & Ulna N (\%) & Tibia N (\%) & Total N (\%) \\
\hline Single Foramen Nutricium & Proximal & $64(73.6 \%)$ & $115(98.3 \%)$ & $179(87.7 \%)$ \\
& Middle & $23(26.4 \%)$ & $1(0.9 \%)$ & $24(11.8 \%)$ \\
& Distal & 0 & $1(0.9 \%)$ & $1(0.5 \%)$ \\
& Total & $87(100 \%)$ & $117(100 \%)$ & $204(100 \%)$ \\
\hline
\end{tabular}

In the measurement of the foramen nutricium, Kumar et al. ${ }^{7}$ were used the following formula: $\mathrm{I}=(\mathrm{DNF} / \mathrm{TL}) \mathrm{x}$ $100 \ll \mathrm{I}$ : foraminal index. Whilst Chandrasekaran ${ }^{9}$ also divided the bone in three equal parts, Joshi et al. ${ }^{11}$ divided the bones in six sections during his observations of the foramen nutricium. In our research, we used forminal index and the method of dividing the bone into three equal sections by means of a ruler. But Kumar et al. ${ }^{7}$ were found of the total 150 foramina, $72(48 \%)$ were in the proximal third and $78(52 \%)$ in the middle third in femur. There were no foramina in the distal third in femur. But in our research; single foramen nutricium was found in the 58 femora. 32 of them were located in the proximal third, 25 in the middle third and one was located in the distal third. Double foramina nutricia in the femur were defined in a total of 60 bones. 53 of them were located in the proximal third, 58 in the middle third and nine were located in the distal third. Murlimanju et al. ${ }^{8}$ was studied 96 humerus, 72 radius and 75 ulna; single foramen nutricium was found in $93.8 \%$ of humerus. There was a double foramen nutricium at $3.1 \%$ of humerus. In Radius, only foramen nutricium was found in $94 \%$, double foramen nutricium was found in $1.4 \%$ and foramen in $4.2 \%$ was not fornut nutricium. There was only one foramen nutricium in $75 \%$ of ulna ${ }^{8}$. According to these results; it was understood that the numbers and localizations of foramen nutricium found in bones show variation different societies. The numbers and locations of the foramina nutricia can be determined through preoperative angiography and the vascular malformations might be eliminated.

Based on Becton and Dickinson, Carroll ${ }^{13}$ suggests that there are three types of methods for the identification of foramina. In his study, Carroll used the 20 gauge and the 24 gauge hypodermic needle. Foramina that were equal to the $24 \mathrm{G}$ hypodermic needle were defined as dominant foramina, foramina that were equal to the $20 \mathrm{G}$ hypodermic needle were defined as middle foramina, and foramina that were smaller than the $20 \mathrm{G}$ hypodermic needle were defined as small foramina ${ }^{13}$. Meanwhile, in his measurements Chandrasekaran ${ }^{9}$ used the needle with the widest diameter to measure the dominant foramina, as well as the following needle dimensions: 18 gauge $=1.2 \mathrm{~mm}, 20$ gauge $=0.9 \mathrm{~mm}, 24$ gauge $=0.55 \mathrm{~mm}$ and 26 gauge $=0.45 \mathrm{~mm}$. In our study a needle of dimensions 21 gauge was used. 
When examining the arteria nutricia variations pertaining to the fibula, Kocabiyik et al. ${ }^{15}$ found the locations of these arteries to be in the middle third of the fibula. In our research we found out that $79.7 \%$ of the foramina nutricia in the fibula were located in the middle section. From this point of view, findings of the two studies support to each other.

According to Kizilkanat et al.'s ${ }^{10}$ study, in $8.1 \%$ of the humeri 3-4 foramen nutricia were observed. In Pereira's ${ }^{13}$ research and in our research no foramen nutricia were observed in the humerus.

According to Kizilkanat et al.'s ${ }^{10}$ study, single foramen nutricia were found in $69.7 \%$ of the humeri; according to Pereira's ${ }^{13}$ study single foramen nutricia were found in $89.7 \%$ of the humeri and in our study single foramen nutricia were found in $88.7 \%$ of the humeri.

While we found single foramen nutricia in $88.7 \%$ of the tibiae, this value was equal to $69.7 \%$ in Kizilkanat et al.'s ${ }^{10}$ study and to $89.7 \%$ in Pereira's ${ }^{13}$ study. Furthermore, double foramen nutricia were found in $10.3 \%$ of the tibiae according to Pereira ${ }^{13}$; in $11.3 \%$ of the tibia according to our study and in $22.2 \%$ of the tibiae according to Kizilkanat et al.

Kizilkanat et $\mathrm{a}^{10}$ and Pereira ${ }^{13}$ found single foramen nutricia in $70.7 \%$ and $75 \%$ of the femora respectively; they further found double foramen nutricia in respectively $28.4 \%$ and $25 \%$ of the femora. Meanwhile, in our study we found single foramen nutricia in $47 \%$ of the femora and double foramen nutricia in $48.8 \%$ of the femora.

Furthermore, the following similar findings were observed in Kizilkanat et al.'s ${ }^{10}$, Pereiras ${ }^{13}$ and our study respectively; single foramen nutricia were found in $99 \%$, $99 \%$ and $100 \%$ of the ulnae in each of the respective studies; single foramen nutricia were found in $99 \%, 99 \%$ and $100 \%$ of the radii in each of the respective studies and single foramen nutricia were found in $99 \%, 95 \%$ and $100 \%$ of the fibulae in each of the respective studies.

These variations in bones reveal the fact that differences and similarities in individuals might be related to periods in the embryological development. A number of theories have been developed as regards these differences in locations and numbers. The theory that has been more widely accepted is Digby's theory which states that nutrient arteries are responsible for the development of the nutrient foramen because of the development of the nutrient canal rather than the development of the osseouse ${ }^{17}$.

It was noticed that there exist statistically significant differences among all the bones of the related area when the number and locations of the foramina nutricia in the long bones of the upper and lower extremities are compared. The present study aimed to take the attention of the surgeons about the distribution patterns of foramina nutricia in the long bones of upper and lower extremities. Finally, the study's findings clearly emphasise the clinical importance of the foramina nutricia's locations in cases of various fractures.

\section{References}

1. Moore KL, Dalley AF, Agur AMR. Clinically Oriented Anatomy 7nd editions, Moore, Philadelphia, Lippincott Williams \& Wikins, A Wolter Kluwer Busines 2014;23.

2. Ferrari S, Bianchi B, Savi A, et al. Fibula free flap with endosseous implants for reconstructing a resected mandible in bisphosphonate osteonecrosis. J Oral Maxillofac Surg 2008;66:999-1003.

3. Şengezer M. Duyulu Osteokutanöz Fibula Flebi ile Penis Rekonstrüksiyonu. Turk Plast Surg 1998;6, 1.

4. Trueta J. The Role of the Vessels in Osteogenesis. J Bone Joint Surg 1963;45:402-18.

5. Brakenbury PH, Corea JR, Blakemore ME. Non-Union of the Isolated Fracture of the Ulnar Shaft in Adults. Injury 1981;12:371-75.

6. Kopuz C, Dabak N, Gülman B, Özyer D. Üst Ekstremite Uzun Kemiklerinin Diafizlerinde Foramen Nutricium'un Sayı ve Yerleşim Analizi. Sbad 1994;5:185-89.

7. Kumar R, Mandloi RS, Singh AK, Kumar D, Mahato P. Analytical and morphometric study of nutrient foramina of femur in Rohilkhand region. IJMHS 2013;3(2):52-4.

8. Murlımanju BV, Prashanth KU, Prabhu VL, Saralaya V, Pai M, Rai R. Morphological and Topographical Anatomy of Nutrient Foramina in Human Upper Limb Long Bones and Their Surgical Importance. Rom J Morphol Embryol 2011;52(3):859-62.

9. Chandrasekaran S, Shanthi KC. Study on the Nutrient Foramina of Adult Humerii. J Clin Diagn Res 2013;7(6):975-7.

10. Kizilkanat E, Boyan N, Ozsahin ET, Soames R, Oguz O. Location, number and clinical significance of nutrient foramina in human long bones. Ann Anat 2007;189:87-95.

11. Joshi H, Doshi B, Malukar O. A Study of the Nutrient Foramina of the Humeral Diaphysis. Natl J Integr Res Med 2011;2(2):14-7.

12. Carroll SE. A Study of the Nutrient Foramina of the Humeral Diaphysis. J Bone Joint Surg 1963;176-81.

13. Pereira GAM, Lopes PTC, Santos A, Silveira FHS. Nutrient Foramina in the Upper and Lower Limb Long Bones: Morphometric Study in Bones of Southern Brazilian Adults. Int J Morphol 2011;29(2):514-20.

14. Shulman SS. Observations on the nutrient foramina of the human radius and ulna. Anat Rec 1959;134;685-97.

15. Kocabiyik N, Yalcin B, Ozan H. Variations of the Nutrient Artery of the Fibula. Clin Anat 2007;20:440-43.

16. Hughes $\mathrm{H}$. The factors determining the direction of the canal for the nutrient artery in the long bones of mammals and birds. Acta Anat 1952;15:261-80.

17. Digby KH. The Measurement of Diaphysial Growth in Proximal and Distal Directions. J Anat Physiol 1916;50 187-88. 